\title{
原子炉用低 $\mathrm{Mn}$ ステンレス鋼の高温脆化に対する
}

\section{$\mathrm{Ti}, \mathrm{Zr}$ の効果 ${ }^{*}$}

\author{
（原子炉炉心用ステンレス鋼に関する研究一I）
}

川畑 正夫**

\author{
Effect of $\mathrm{Ti}$ and $\mathrm{Zr}$ on Hot Shortness of Low-Mn Stainless \\ Steels for Reactor Materials.
}

(Studies on the stainless steels for reactor materials-I)

Masao Kawahata

\section{Synopsis:}

The present investigation was undertaken to develop the low-Mn AISI type 347 stainless: steel for nuclear reactor materials. The hot shorthness caused by lowering Mn content in. steel, and favorable effect of $\mathrm{Ti}$ or $\mathrm{Zr}$ addition on low-Mn alloys.

The experimental results obtained were as follows;

(1) Mn content in steel could be reduced to below $0.10 \%$ through careful selection of raw materials.

(2) The hot shortness was apt to occur when Mn content in steel was decreased to $0.60 \%$. Addition of $\mathrm{Ti}$ or $\mathrm{Zr}$ over $0.10 \%$ presumably was effective against the hot shortness.

(3) It can be considered that the drop in hot ductility for low-Mn steels and the solving this problem by the addition of $\mathrm{Ti}$ or $\mathrm{Zr}$ might not only depend on the type of oxides and oxygen content, but also mainly on the morphology of sulphides.

\section{I. 緒}

ステンレス龬を原子炉炉心用材料として使用する場合 には，一般の構造用ステンレス鋼としての物理的，機械 的性質および化学的性質の他に核的特性すなわち中性子 吸収断面積, 照射損傷特性, さらに誘導放射能の強さな どを考虑しなければならず，通常の工業用規格鋼種では 核的特性において若干の問題を含えでいる.

オーステナイト・ステンレス鋼中に不純物として存在 する Co および Ta は中性子吸収断面積が大きく, 半 減期の長い同位元素に变わるために, 中性子経済, 炉の 保守補修の点で好ましくなく，また合金元素として存在 する Mn も中性子吸取断面積が大きく, 強い $\boldsymbol{r}$ 線を放 射する短寿命核種を生成するために，Co および Ta と 同様に低下する必要がある.しかし Mnの低下に関する 研究は BEEGHLY1)，(HILD ${ }^{2)}$ および長谷川3)によつてな されている程度である. 従つて原子炉炉心用ステンレネ 鉵においては核的特性に有害な Co, Ta および Mn は 極力低下しなければならないが，原子师工学上の十分な 制限条件の明らかでない今日，経斉性をも考虑しながら 工業的規模において可能な範囲に極力これら元素を低減
する場合の治金学的可能性および製造上の問題点の解明 にあたつては, 材料の性質を十分に研究しておく必要が. ある.

著者はこのような観点から耐食性，高温強度および価 格の点で優れ，広く原子师用として使用されている AISI 347 鋼をとりあげ Co, Ta および Mn を低减す る場合の諸問題について一連の研究を行なつた。本研究 はそのうち Mn の低下に伴う高温脆性をとり゙あげ, 從 来その要因として指摘されている硫化物, 酸化物などと 関連させて治金学的考察を試み, さらに Ti，Zr なとを 添加して高温脆性の回復に関する知見を得たのでここに 報告する.

\section{II. 実 鞅 方 法}

試料は $48 \mathrm{kVA}$ の塩基性高周波誘導炉を用いて溶解 し $75 \mathrm{~mm}$ 角 $\times 120 \mathrm{~mm}$ 高さの角型鋼塊を溶彆した. 試 料の化学組成を Table 1 に示す. いずれも AISI 347 鋼の組成を基本にして，B系列の試料は Mnを・0・10\%

* 昭和35年 4 月本会境演大会にて発表

** 日本冶金工業株式会社川崎製造所 
Table 1. Chemical analysis of steels investigated.

\begin{tabular}{|c|c|c|c|c|c|c|c|c|c|c|c|c|c|}
\hline Steels & $\begin{array}{l}\text { Heat } \\
\text { No. }\end{array}$ & C & $\mathrm{Si}$ & $\mathrm{Mn}$ & $\mathbf{P}$ & $\mathbf{S}$ & $\mathrm{Ni}$ & $\mathrm{Cr}$ & $\mathrm{Nb}$ & $\mathrm{Ta}$ & $\mathbf{N}$ & $\begin{array}{c}\mathbf{O} \\
(\mathrm{ppm})\end{array}$ & Others \\
\hline 0.0 & $\begin{array}{r}\text { B-1 } \\
2 \\
3 \\
4 \\
5 \\
6 \\
7\end{array}$ & $\begin{array}{l}0.055 \\
0.069 \\
0.060 \\
0.065 \\
0.073 \\
0.065 \\
0.068\end{array}$ & $\begin{array}{l}0.24 \\
0.22 \\
0.54 \\
0.47 \\
0.57 \\
0.52 \\
0.42\end{array}$ & $\begin{array}{l}0 \cdot 17 \\
0 \cdot 33 \\
0 \cdot 61 \\
1 \cdot 08 \\
1 \cdot 53 \\
1 \cdot 81\end{array}$ & $\begin{array}{l}0.003 \\
0.009 \\
0.007 \\
0.010 \\
0.010 \\
0.006 \\
0.006\end{array}$ & $\begin{array}{l}0.016 \\
0 \cdot 015 \\
0.015 \\
0.017 \\
0.013 \\
0.015 \\
0.013\end{array}$ & $\begin{array}{l}11 \cdot 88 \\
11 \cdot 55 \\
11 \cdot 85 \\
10 \cdot 07 \\
11 \cdot 25 \\
11 \cdot 28 \\
11 \cdot 37\end{array}$ & $\begin{array}{l}16 \cdot 56 \\
18 \cdot 55 \\
18 \cdot 40 \\
18 \cdot 41 \\
18 \cdot 07 \\
18 \cdot 07 \\
17 \cdot 75\end{array}$ & $\begin{array}{l}0 \cdot 69 \\
0 \cdot 75 \\
0 \cdot 77 \\
0 \cdot 73 \\
0 \cdot 74 \\
0 \cdot 74 \\
0 \cdot 67\end{array}$ & $\begin{array}{l}0.06 \\
0.07 \\
0 \cdot 08 \\
0 \cdot 06 \\
0 \cdot 06 \\
0.06 \\
0.04\end{array}$ & $\begin{array}{l}0.019 \\
0.036 \\
0.028 \\
0.033 \\
0.035 \\
0.035 \\
0.035\end{array}$ & $\begin{array}{r}272 \\
82 \\
91 \\
82 \\
84 \\
76 \\
71\end{array}$ & $\begin{array}{l}- \\
- \\
- \\
-\end{array}$ \\
\hline $\begin{array}{c}0 \sim 0.43 \% \mathrm{Ti} \\
\sim 0.06 \% \mathrm{Mn}\end{array}$ & $\begin{array}{r}\text { C-1 } \\
2 \\
3 \\
4 \\
5\end{array}$ & $\begin{array}{l}0.058 \\
0.056 \\
0.056 \\
0.053 \\
0.056\end{array}$ & $\begin{array}{l}0 \cdot 26 \\
0 \cdot 31 \\
0 \cdot 51 \\
0 \cdot 61 \\
0 \cdot 65\end{array}$ & $\begin{array}{l}0.06 \\
0.07 \\
0.07 \\
0.07 \\
0.06\end{array}$ & $\begin{array}{l}0.001 \\
0.001 \\
0.002 \\
0.002 \\
0.001\end{array}$ & $\begin{array}{l}0.012 \\
0 \cdot 014 \\
0 \cdot 011 \\
0 \cdot 012 \\
0.011\end{array}$ & $\begin{array}{l}12 \cdot 00 \\
12 \cdot 15 \\
12 \cdot 02 \\
11 \cdot 83 \\
12 \cdot 00\end{array}$ & $\begin{array}{l}18 \cdot 53 \\
18 \cdot 30 \\
18 \cdot 06 \\
18 \cdot 68 \\
18 \cdot 40\end{array}$ & $\begin{array}{l}0.69 \\
0.69 \\
0.66 \\
0.77 \\
0.76\end{array}$ & $\begin{array}{l}0 \cdot 05 \\
0 \cdot 11 \\
0 \cdot 11 \\
0 \cdot 12 \\
0 \cdot 11\end{array}$ & $\begin{array}{l}0.015 \\
0.019 \\
0 \cdot 019 \\
0 \cdot 016 \\
0.020\end{array}$ & $\begin{array}{r}308 \\
224 \\
167 \\
78 \\
58\end{array}$ & $\begin{array}{c}\text { Ti tr } \\
0.04 \\
0.16 \\
0.23 \\
0.43\end{array}$ \\
\hline $\begin{array}{c}\text { D. } 36 \sim 0.96 \% \mathrm{Si} \\
\text { (Added as } \\
\mathrm{Ca}-\mathrm{Si} \text { ) } \\
\sim 0.15 \% \mathrm{Mn}\end{array}$ & $\begin{array}{r}\mathrm{D}-1 \\
2 \\
3 \\
4\end{array}$ & $\begin{array}{l}0 \cdot 038 \\
0 \cdot 044 \\
0 \cdot 038 \\
0 \cdot 044\end{array}$ & $\begin{array}{l}0.35 \\
0.55 \\
0.69 \\
0.96\end{array}$ & $\begin{array}{l}0 \cdot 11 \\
0 \cdot 12 \\
0 \cdot 12 \\
0 \cdot 13\end{array}$ & $\begin{array}{l}0 \cdot 010 \\
0 \cdot 012 \\
0 \cdot 013 \\
0 \cdot 014\end{array}$ & $\begin{array}{l}0 \cdot 015 \\
0 \cdot 013 \\
0 \cdot 013 \\
0 \cdot 013\end{array}$ & $\begin{array}{l}12 \cdot 70 \\
12 \cdot 72 \\
12 \cdot 70 \\
12 \cdot 72\end{array}$ & $\begin{array}{l}18 \cdot 33 \\
18 \cdot 52 \\
18 \cdot 12 \\
18 \cdot 42\end{array}$ & $\begin{array}{l}0.63 \\
0.56 \\
0 \cdot 65 \\
0 \cdot 64\end{array}$ & $\begin{array}{l}0 \cdot 06 \\
0 \cdot 04 \\
0 \cdot 05 \\
0 \cdot 06\end{array}$ & $\begin{array}{l}0 \cdot 036 \\
0 \cdot 034 \\
0 \cdot 026 \\
0 \cdot 039\end{array}$ & $\begin{array}{l}- \\
-\end{array}$ & $\begin{array}{c}- \\
- \\
-\end{array}$ \\
\hline $\begin{array}{c}0 \cdot 27 \sim 0 \cdot 76 \% \mathrm{~V} \\
\sim 0 \cdot 15 \% \mathrm{Mn}\end{array}$ & $\begin{array}{r}\mathrm{E}-1 \\
2 \\
3\end{array}$ & $\begin{array}{l}0.038 \\
0.029 \\
0.033\end{array}$ & $\begin{array}{l}0 \cdot 29 \\
0 \cdot 46 \\
0 \cdot 39\end{array}$ & $\begin{array}{l}0.14 \\
0.15 \\
0.11\end{array}$ & $\begin{array}{l}0.012 \\
0.012 \\
0.010\end{array}$ & $\begin{array}{l}0 \cdot 017 \\
0 \cdot 017 \\
0 \cdot 017\end{array}$ & $\begin{array}{l}12 \cdot 70 \\
12 \cdot 03 \\
12 \cdot 60\end{array}$ & $\begin{array}{l}17 \cdot 00 \\
17 \cdot 80 \\
18 \cdot 20\end{array}$ & $\begin{array}{l}0 \cdot 73 \\
0 \cdot 83 \\
0 \cdot 79\end{array}$ & $\overline{-}$ & $\begin{array}{l}0 \cdot 040 \\
0 \cdot 040 \\
0 \cdot 034\end{array}$ & $\begin{array}{l}289 \\
220 \\
166\end{array}$ & $\begin{array}{l}\text { V } 0.27 \\
0.41 \\
0.76\end{array}$ \\
\hline $\begin{array}{c}\cdot 04 \sim 0 \cdot 12 \% \\
\mathrm{Zr} \text { (Added } \\
\text { as } \mathrm{Si}-\mathrm{Zr} \text { ) } \\
\sim 0.15 \% \mathrm{Mn}\end{array}$ & $\begin{array}{r}F-1 \\
2\end{array}$ & $\begin{array}{l}0.049 \\
0.064\end{array}$ & $\begin{array}{l}0 \cdot 56 \\
0 \cdot 85\end{array}$ & $\begin{array}{l}0 \cdot 14 \\
0 \cdot 14\end{array}$ & $\begin{array}{l}0.008 \\
0.007\end{array}$ & $\begin{array}{l}0.017 \\
0 \cdot 014\end{array}$ & $\begin{array}{l}12 \cdot 70 \\
12 \cdot 48\end{array}$ & $\begin{array}{l}18 \cdot 11 \\
18 \cdot 57\end{array}$ & $\begin{array}{l}0 \cdot 74 \\
0 \cdot 77\end{array}$ & - & - & - & $\begin{array}{ll}\operatorname{Zr} & 0.04 \\
& 0.12\end{array}$ \\
\hline $\begin{array}{l}0.02 \sim 0.48 \\
\% \mathrm{Al} \\
\sim 0.06 \% \mathrm{Mn}\end{array}$ & $\begin{array}{r}\text { G- } 1 \\
2 \\
3 \\
4 \\
5\end{array}$ & \begin{tabular}{l|}
0.059 \\
0.057 \\
0.058 \\
0.068 \\
0.060
\end{tabular} & $\begin{array}{l}0.43 \\
0.64 \\
0.68 \\
0.66 \\
0.68\end{array}$ & $\begin{array}{l}0.06 \\
0.02 \\
0.09 \\
0.02 \\
0.02\end{array}$ & $\begin{array}{l}0 \cdot 010 \\
0 \cdot 009 \\
0.009 \\
0 \cdot 009 \\
0.009\end{array}$ & $\begin{array}{l}0 \cdot 008 \\
0 \cdot 007 \\
0 \cdot 006 \\
0 \cdot 007 \\
0 \cdot 009\end{array}$ & $\begin{array}{l}11 \cdot 74 \\
11 \cdot 81 \\
11 \cdot 78 \\
11 \cdot 72 \\
11 \cdot 64\end{array}$ & $\begin{array}{l}17 \cdot 60 \\
17 \cdot 33 \\
17 \cdot 46 \\
17 \cdot 56 \\
17 \cdot 69\end{array}$ & $\begin{array}{l}0.61 \\
0.65 \\
0.68 \\
0.65 \\
0.69\end{array}$ & $\begin{array}{l}- \\
- \\
-\end{array}$ & $\begin{array}{l}- \\
- \\
-\end{array}$ & $\begin{array}{r}301 \\
99 \\
56 \\
49 \\
44\end{array}$ & $\begin{array}{c}\text { A1 } 0.022 \\
0.071 \\
0.081 \\
0.26 \\
0.48\end{array}$ \\
\hline $\begin{array}{l}10 \sim 100 \mathrm{ppm} \\
\text { O } \\
\text { (Vacuum- } \\
\text { melted) }\end{array}$ & $\begin{array}{r}\mathbf{K} \mathbf{-} 5 \\
6 \\
8 \\
9 \\
11 \\
12 \\
13\end{array}$ & $\begin{array}{l}0.043 \\
0.029 \\
0.048 \\
0.022 \\
0.022 \\
0.028 \\
0.049\end{array}$ & $\begin{array}{l}0 \cdot 41 \\
0 \cdot 38 \\
0 \cdot 42 \\
0 \cdot 45 \\
0 \cdot 42 \\
0 \cdot 53 \\
0 \cdot 51\end{array}$ & $\begin{array}{l}0.02 \\
0.03 \\
0.02 \\
0.02 \\
0.01 \\
0.01 \\
\text { tr }\end{array}$ & $\begin{array}{l}0.006 \\
0.006 \\
0.006 \\
0.008 \\
0.005 \\
0.008 \\
0.006\end{array}$ & $\begin{array}{l}0.011 \\
0.010 \\
0 \cdot 011 \\
0.010 \\
0.009 \\
0.009 \\
0 \cdot 009\end{array}$ & $\begin{array}{l}12 \cdot 45 \\
12 \cdot 75 \\
13 \cdot 05 \\
12 \cdot 85 \\
12 \cdot 90 \\
12 \cdot 81 \\
13 \cdot 23\end{array}$ & $\begin{array}{l}19 \cdot 70 \\
20 \cdot 14 \\
19 \cdot 65 \\
19 \cdot 65 \\
19 \cdot 90 \\
20 \cdot 63 \\
19 \cdot 68\end{array}$ & $\begin{array}{l}0.81 \\
0.70 \\
0.85 \\
0.84 \\
0.80 \\
0.89 \\
0.82\end{array}$ & $\begin{array}{l}- \\
- \\
z \\
-\end{array}$ & $\begin{array}{l}0.009 \\
0.010 \\
0.010 \\
0.008 \\
0.008 \\
0.006 \\
0.008\end{array}$ & $\begin{array}{l}98 \\
82 \\
45 \\
63 \\
53 \\
32 \\
15\end{array}$ & $\begin{array}{l}- \\
z \\
z \\
-\end{array}$ \\
\hline
\end{tabular}

の低レベルより通常の AISI 347 鋼の Mn 量まで変化 させたもの, 試料 C， D， E，Fおよび G系列はそれぞ れ Mn 量は 0.15\% 以下におさえて $\mathrm{Ti}, \mathrm{Ca}, \mathrm{V}, \mathrm{Zr}$ および Alを添加したものである. 試料 $\mathrm{kV}$ 系列は誘 導式真空溶解炉により Mn 0.01\% まで低下し, 酸素含 有量を 15〜100 ppm に変化したものである.これら鋼 塊は $20 \mathrm{~mm} \oint$ 丸棒に鍛造後 $1030^{\circ} \mathrm{C} 1 \mathrm{~h}$ 急冷の溶態化 処理を施して供試材とした.

試験はこれら試料について，熱間脆性におよほす $\mathrm{Mn}$, $\mathrm{Ti}, \mathrm{V}, \mathrm{Ca}, \mathrm{Zr}$ および Al の影響について実施した. 熱間脆性を検知する方法として熱間捩り試験のほかに， 高温衝繋試験*すなわち JIS 3 号衝撃試片を用いて 1050〜 $1350^{\circ} \mathrm{C}$ における高温シャルピー試験を行ない,

* また著者は従来䋛目無し管用オーステナイト・ステンレス甪のマン

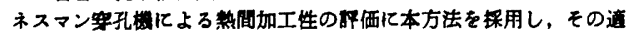
応珄の確琩をみている。
試片の吸収エネルギーと試験後の試片の破断形態から熱 間脆性を定性的に判別し, 試片の破断した領域を脆化範 囲とみなした。この結果は熱間㨝り試験の結果とも一致 している.

Fig. 1 に AISI 347 鋼に関する両者の試験結果を比 較して示すが，いずれも $1200^{\circ} \mathrm{C}$ 以上では変形能が低下 し材料の脆化現象を察知することができる.

\section{III. 実験結果および考察}

\section{（1） Mn 含有量の熱間脆性におよぼす影響}

Mnを 0.05\%〜1.81\%に変化したB系列の試片につ いて高温衝撃試験を行ない, 各試験温度での Mn 量とシ カルピー衝撃値の関係を Fig. 2 に示す. Mn 含有量が 低下するにつれて高温衝撃値は低下し試験片は破断する ようになる.これは試験温度における材料の変形能の減 少を示唆し, この傾向は試験温度の上昇につれて著しく 

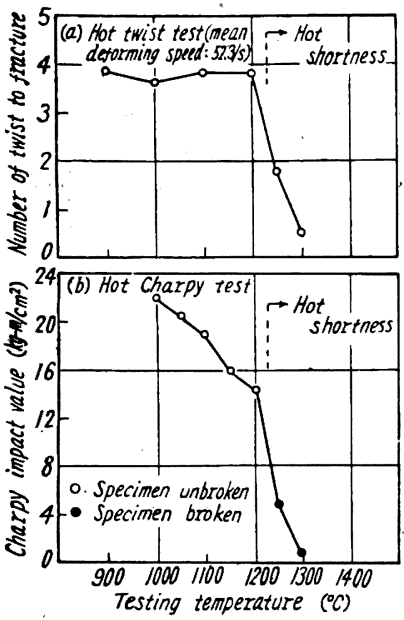

Fig. 1. High-temperature ductility of AISI 347 stainless steel observed by hot twist test (a) and high temperature impact test (b).

ける Ti 量之高温衝撃値の関係を Fig. 4 に，また試片 の破断形態から判定した脆化範囲を. Fig. 5 に示す.こ の結果 $\mathrm{Ti} 0 \cdot 10 \%$ 以上添加すると低 $\mathrm{Mn}$ 合金にあらわ

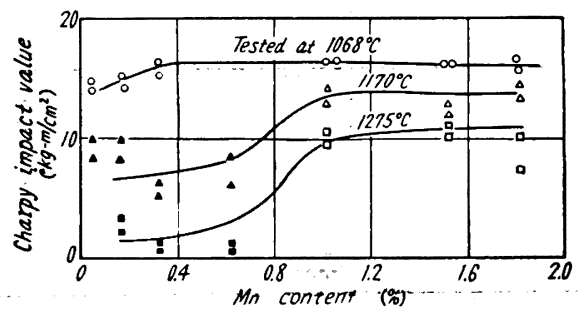

Solid points: Specimens were broken

Fig. 2. Effect of $\mathrm{Mn}$ content on hightemperature ductility of 347 stainless steels.

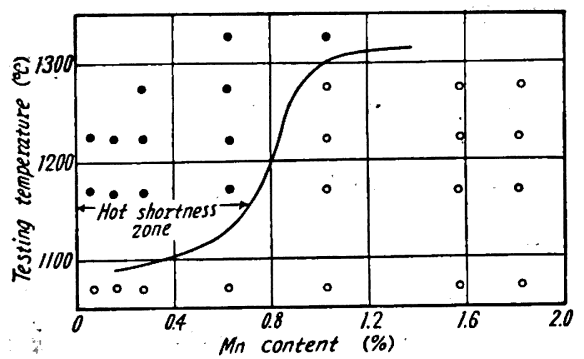

O Specimens were unbroken Specimens were broken

Fig. 3. Effect of $\mathrm{Mn}$ content on hot shortness range of 347 stainless steels. (Observed by high-temperature impact test.)

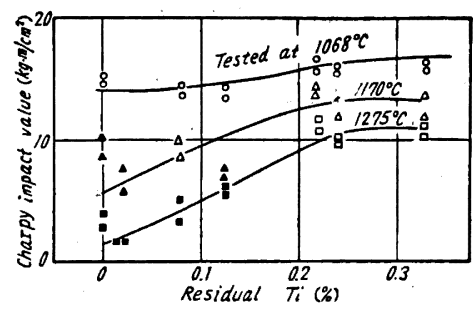

Solid points Specimens were broken

Fig. 4. Effect of $\mathrm{Ti}$ content on hightemperature ductility of low-Mn 347 stainless steels.

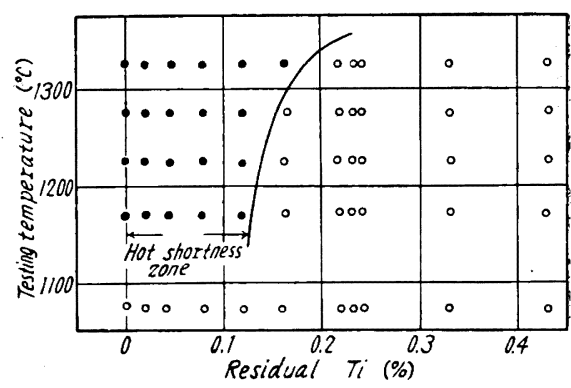

O Specimens were unbroken

- Specimens were broken

Fig. 5. Effect of $\mathrm{Ti}$ content on hot shortness range of low-Mn 347 stainless steels.

(Observed by high-temperature impact test.)

れた脆化現象が改善

され，通常の $\mathrm{Mn}$ 含

有量の鋼種なみの靫

性が得られる。

さらに Ti に依る 熱間脆性の改善効果 を, 熱間㨝り試験に よつて確認した結果 Fig.6に示すように

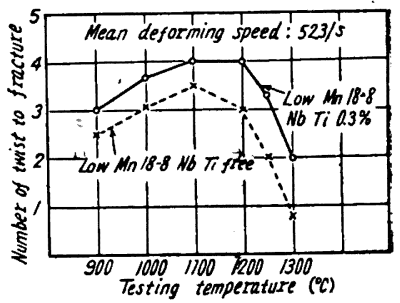

Fig. 6. Effect of $\mathrm{Ti}$ content on hot ductility of low-Mn AISI 347 stainless steels. Ti 入りの方が優れ (Observed by hot twist test.) た高温変形能を有することが確認された。

（3）低 Mn 合金の高温脆性におよほす $\mathrm{V}, \mathrm{Ca}, \mathrm{Zr}$, および Al の影響

Ti の場合と同様に Mn 0.10\% 以下にした AISI 347 組成に V, Ca, Zr および Al 添加量を変化した D, E，FおよびG系列試料についての結果を Fig.7〜 Fig. 10に示す. Fig. 7 はV，Fig. 8 は Ca, Fig. 9 は Zr さらに Fig. 10 は Al を添加した場合の熱間脆化範囲 におよほすそれぞれの添加元素の効果を示したものであ る.なお $\mathrm{Ca}$ は Ca-Si 母合金で (Ca 35\%； Si 60\%) 
添加したもので便宜的に合金中の $\mathrm{Si} \%$ で表示した.

これらの結果から明らかなように Z r は Ti と同様 に高温脆化現象の改善に著しい胁果を示すことが判明し

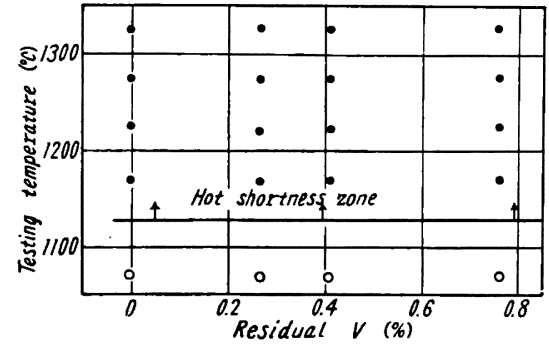

O Specimnes were unbroken

- Specimens were broken

Fig. 7. Effect of $\mathrm{V}$ content on hot shortness range of low-Mn 347 stainless steels. (Observed by high-temperature impact test.)

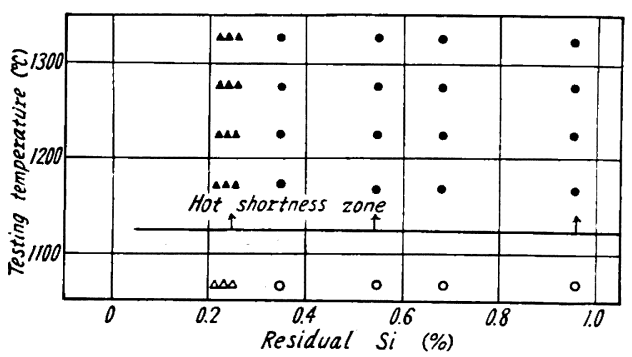

Steels deoxidized with $\mathrm{Ca}-\mathrm{Si}$,

O Specimens were unbroken

Specimens were broken

Steels deoxidized with $\mathrm{Fe}-\mathrm{Si}$,

$\triangle$ Specimens were unbroken

$\Delta$ Specimens were broken

Fig. 8. Effect of residual $\mathrm{Si}$ on hot shortness range of low-Mn 347 stainless steels. (Observed by high-temperature impact test.)

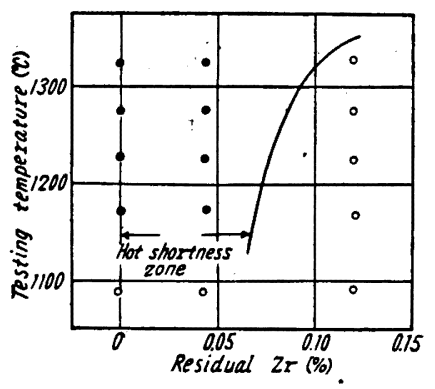

O Specimens were unbroken

- Specimens were broken

Fig. 9. Effect of residual $\mathrm{Zr}$ on hot shortness range of low-Mn 347 stainless steels. (Observed by high-temperature impact test.)
た.これに対して $\mathrm{V}, \mathrm{Ca}$ および $\mathrm{A} 1$ 処理では脆化現象 の改善効果は期待できないことが明白となつた.

（4）真空溶解した低 Mn 合金の高温脆性

誘導式真空溶解法により，Mn 0.02\% 以下に低下し 酸素量を 15〜100 ppm に変化した $\mathrm{kV}$ 系列の試料に ついて高温衝撃試験により, 酸素含有量と脆化範囲の関 係を追求し結果を Fig. 11 に示す. これより高温脆化 におよぼす酸素の影響は若千認められるが，前述までの $\mathrm{Mn}$ また注低 Mn 合金における Ti, Zr の影響にくらべ ると余り顕著ではなく，通常の製鋼作業条件でえられる 酸素量の变化範囲では酸素の影響は特に著しいとはいえ ない.

（5）非金属介在物の形態

a) 酸化物系介在物 R. A. PERKINS4) らはオース テナイト・ステンレス鋼の熱間加工性におよぼす各種脱 酸成分の影響を調査して，熱間加工性におよぼす溶解条 件の因子として酸化物系介在物の形態変化を指摘してい る. 筆者の主として光学顕微鏡によつて観察した結果で はMnを変化したB采列試料では，Mnの低下につれて クローム硅酸塩およびその他の不透明硅酸塩がやや減小

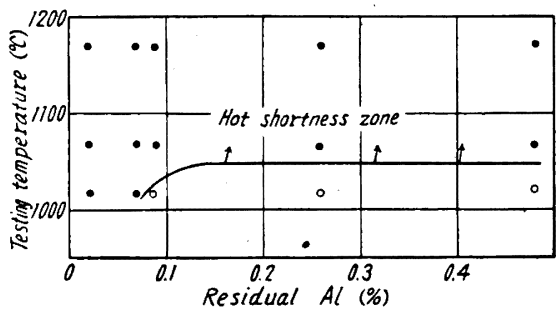

O Specimen were unbroken Specimen were broken

Fig. 10. Effect of Al content on hot shortness zone of low-Mn 347 stainless steels. (Observed by high temperature impact test.)

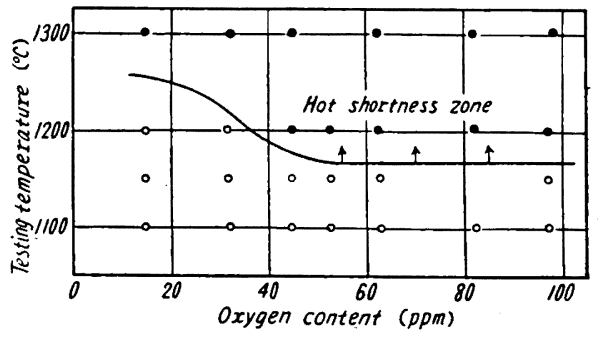

O Specimens were unbroken Specimens were broken

Fig. 11. Effect of oxygen content on hot shortness range of low-Mn 347 stainless steels. (Observed by high-temperature impact test.) 
しガラス状硅酸が増加する傾向にあるが全般的に著しい 形態変化は認められない．また Table 1 に示すように 酸素量も変化しない. $\mathrm{Ti}$ 添加の $\mathrm{C}$ 系列試料では $\mathrm{Ti}$ の 増加につれて硅酸塩が隇少しイルミナイトと思われる特 徽ある介在物が認められるようになり、酸素量も $\mathrm{Ti}$ と ともに減少の傾向を示す.

以上のことから Mn を低下した場合にあらわれる高温 脆化は, 鋼中の不純物が通常レベルの場合では, 単に酸 化物のみの問題では解明されず, オーステナイト・ステ ンレス鋼においても，炭素鋼の場合と同じく硫化物の形 態も重要な因子として考えなければならないであろう.

b ）硫化物系介在物の形態 $18-8 \mathrm{Nb}$ 鋼の $\mathrm{Mn}$ を 低下した場合およびこれにさらに Ti を添加した場合の 硫化物の形態にういて定性的な見解をえるために, 光学 顕微鏡による観察およびサルファープリント, 化学分析 を併用した. 硫黄の分析に燃焼法と発生法を併用するこ とにより, 比較的酸に安定な硫化物として存在する場合 には発生法に上る硫黄分析値は低く, 一方酸に可溶性硫 化物の場合には発生法によつても, 燃焼法によつてえら れる総硫黄\%に近い値がえられる.これより前者に属す る $\mathrm{Ti}, \mathrm{Nb}, \mathrm{Cr}$ の硫化物と後者に属する $\mathrm{Fe}, \mathrm{Mn}$ の 硫化物との判別が可能である. またこのような理由から サルファープリントによつても, 鋼中の硫化物の酸に対 する特性が察知される5). 試験結果は Table 2 に示す ごとく低 Mn 組成ではサルファープリントに対して感受

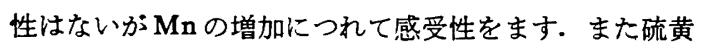
の分析値でも $\mathrm{Mn}$ の増加とともに酸に可溶性硫黄\%が増 加し $\mathrm{Mn}$ 硫化物の増加を示唆するものと推察される. 一 方 Table 2 に示す $\mathrm{T} i$ 添加の場合は $\mathrm{T} i$ 硫化物が酸に 不溶性であるために, このような現象浔認められない. この点に関してはさらに電解抽出残渣の X 線回折により 追求した。

鋼中の硫化物を電解抽出（10\%クエン酸ソーダ+ $5 \%$

Table 2. Results of sulphur print and determination of $\mathrm{HCl}$-soluble and-insoluble sulphide.

\begin{tabular}{l|c|c|c}
\hline $\begin{array}{l}\text { Heat } \\
\text { No. }\end{array}$ & $\begin{array}{c}\text { Sulphur print } \\
\text { sensitivity }\end{array}$ & $\begin{array}{c}\text { HCl- } \\
\text { soluble } \\
\text { S }(\%)\end{array}$ & $\begin{array}{c}\text { HCl- } \\
\text { insoluble } \\
\text { S }(\%)\end{array}$ \\
\hline KV-13 & Not sensive & 0.001 & 0.007 \\
B-2 & Not sensive & 0.004 & 0.010 \\
B-4 & Slightly sensive & 0.010 & 0.002 \\
B-7 & Moderately sensive & 0.014 & 0.002 \\
\hline C-1 & Not sensive & 0.002 & 0.011 \\
C-2 & "1 & 0.002 & 0.013 \\
C-3 & " & 0.002 & 0.012 \\
C-4 & " & 0.002 & 0.012 \\
\hline
\end{tabular}

塩酸, 電流密度 $\left.30 \mathrm{~mA} / \mathrm{cm}^{2}\right)$ によつて回収し, $\mathrm{X}$ 線回 折に供し形態分析を行なつた結果, 通常の $\mathrm{Mn}$ 含くむ AISI 347 鋼では f. c. c. MnS が, 低 Mn 組成で Ti を含む場合には hexagonal TiS が検知された.

さらに著者ら ${ }^{6)} \mathrm{Ni}-\mathrm{Cr}, \mathrm{Ni}-\mathrm{Cr}-\mathrm{Nb}$ オーステナ1 卜鋼の Mnを低下した場合，および Ti，Zr を添加した 場合の硫化物の形態変化を, 高硫黄 ( $\mathrm{S}: 0.5 \sim 1 \cdot 0 \%$ ) 実験組成合金について究明した結果, 通常レベルの Mn を含有する場合には MnS であるが，Mn を低下する と $\mathrm{Ni}-\mathrm{Cr}$ 鋼では $\mathrm{CrS} \mathrm{Ni-Cr-Nb}$ 鋼では $\mathrm{Nb}$-硫化物 として存在し, 低 $M n$ 組成で $\mathrm{Ti}, \mathrm{Zr}$ を含む場合には $\mathrm{Nb}$ の有無にかかわらず $\mathrm{TiS}, \mathrm{Zr}_{3} \mathrm{~S}_{4}, \mathrm{Zr}_{3} \mathrm{~S}_{2}$ として固 定されることが判明している. Fig. 12 は以上の $\mathrm{X}$ 線回 折図型で同図（a）は $\mathrm{S}=0.5 \%$ を含む 18-8 Cr-Ni 銅 の回折線で f. c. c. MnS を, (c) は S:0.48\% Ti 1.99\%を含む 18-8 Nb 鋼のそれで NiAS 型hexagonal TiS を示す. (b)(d)はそれぞれ Mn 1・81\% の B-7 と低 $\mathrm{Mn}$ 組成で $\mathrm{Ti} 0.43 \%$ を含む C-5 試片の残渣 の回折線であり, MnS と TiS の回折線に一致する線 よりそれぞれの相の存在がうかがえる.

(6) 第三元素添加勃果に対する考察

オーステナイト・ステンレス鋼の熱間加工性におよほ す因子としては, 森島》はオーステナイトの定度すな わち成分バランスとともに酸素 量の影響をあげ，また PERKINS, BINDER) らも各種脱酸生成物の形態を明らか にしている. 鋼中の硫化物の影響に関しては, 炭素銅な いし低合金鋼に関する研究名) は数多く認められるが, オ ーステナイト・ステンレス鋼についての報告はみあたら ない。

本実験に適応した $\mathrm{Mn}$ の代替元素としての第 3 元素の 脱酸に対する勃果を考察すると, 通常の製鋼手段で溶製 したステンレス鋼は, 平衡論的観点からみると溶鋼中で の脱酸平衡は Si により成立しているものと考えられ, $\mathrm{Ti}, \mathrm{Zr}, \mathrm{Al}$ の添加による眖酸平衡は Si の場合より下

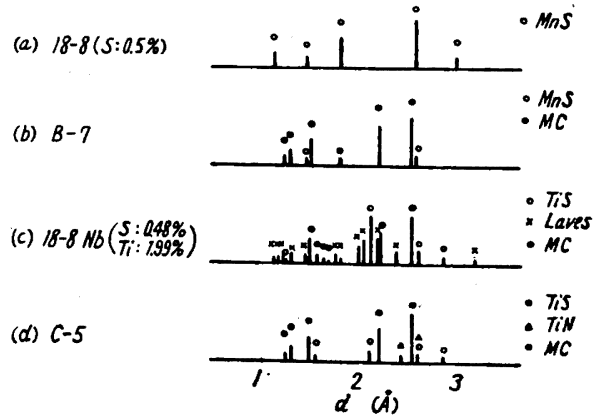

Fig. 12. X-ray diffraction pattern. 
限に到達することが予想される.またVによつては Mn と同様に Si によつて脱酸平衡は成立し, $\mathrm{Ca}-\mathrm{Si}$ につい ては Ca は酸化物の生成熱は大きく強力な脱酸作用が期 待されるが $\mathrm{Ca}$ の蒸気圧の大きいことや溶鋼中での溶解 度のないことから，その効果は添加条件に左右されるも のと考えられる。

一方硫化物に対する効果は通常組成のステンレス鋼は Mn との平衡関係で律せられるものとみなされる.低 $\mathrm{Mn}$ 組成に上記第 3 元素を添加した場合の効果を考察す ると $\mathrm{Ti}, \mathrm{Zr}$ の場合には, Zr 硫化物の熱力学的数值は 測定されていないが， Ti 硫化物の生成熱の大きいこと や, Austin ${ }^{8)}$ らの結果から硫黄の安定化勃果が当然予想 される. Vについては硫化物の熱力学的数值は不明であ るが大きな効果は期待出来ない. また $\mathrm{Ca}-\mathrm{Si}$ の場合は 塩基性鋼滓下での $\mathrm{S}+\mathrm{Ca} \rightarrow(\mathrm{CaS})$ の強力な脱硫効果が 期待されるが，これも脱酸の場合と同様にその効果は添 加条件に左右されるものと考えられる．Alに関しては $\mathrm{Al}_{2} \mathrm{~S}_{3}$ の生成が報ぜられているが, 熱力学的数值も不明 でありまた $\mathrm{A} 1, \mathrm{~S}$ 濃度の相当高い場合の他はその存在 が確認出来ないことからして，Al による $\mathrm{S}$ の固定化は 期待出来ない.

本実験の結果を総括すると, 酸素と熱間脆性の関係は 真空溶解により Mn を痕跡まで低下し，酸素含有量を著 しく低下した合金についても，また $\mathrm{Al}$ を添加して酸素 量を異にする試料についても，Mn の低下に起因する熱 間脆性の顕著な改善効果は得られなかつた. 一方 $\mathrm{Ti}$, Zr を添加したものは顕著な脱酸効果を示すと同時に著 しい硫化物の形態変化が認められ，これらは低 $\mathrm{Mn}$ 組成 で現出した熱間脆性を顕著に改善ずる. 以上のことから 低 $\mathrm{Mn}$ 組成で現出する熱間脆性は酸素ないし酸化物の影 循も考えられるが，酸素量にあまり影響せず硫化物の固 定に勃果のある Mn で脆性が改善され, 一方これとは逆 な Al では脆性回復が顕著でないことから，このような 低 $\mathrm{Mn}$ 組成においては硫化物の形態がより支配的であろ うと考えられる.

すなわち低 $\mathrm{Mn}$ 組成で存在する $\mathrm{CrS}, \mathrm{Nb}$ 硫化物が
Mn により MnS に, Ti, Zr の添加により TiS あるい は $\mathrm{Zr}_{3} \mathrm{~S}_{2}, \mathrm{Zr}_{3} \mathrm{~S}_{4}$ となり硫化物の形態は変化する. 従つ て低 $\mathrm{Mn}$ 組成で現出する熱間脆性および $T \mathrm{i}, Z \mathrm{r}$ による 脆性の改善効果は, これら硫化物の形態変化に密接な関 係にあるものと考えられる。

\section{IV. 結言}

原子炬用低 Mn オーステナイト・ステンレス鋼の開発 のために行なつた研究の一環として, Mn の低下に伴う 熱間脆化現象に関して究明した結果次の結論を得た.

（1）実験室的誘導炉溶解により製鋼原料を選択して Mn 0*10\% 以下に低下することが出来る. さらに真空 溶解法をもちいると Mnを痕跡程度まで除去することが 出来る.

（2）一般の工業的製品の純度では Mn 含有量を0・60 \%以下にすると熱間の脆化現象が現出する.

（3） Mn の低下によつて惹起する熱間加工性の低下 は Ti または Zr の添加により解决される. その主因が 酸化物であるか硫化物であるかの結論をえるまでには到 達しなかつたが, 非金属介在物の形態に起因するものと 考え得る.

本研究は昭和 33 年度科学技術庁, 原子力平和利用補 助研究により実施したものの一部であることを附記し謝 意を表する。

（昭和36年9月寄稿）

\section{交献}

1) H. F. Beeghly: J. Metals, Dec. (1956)

2) Н. C. Сhild et al,: J. Iron and Steel Inst. (U.K.) Dec. (1958)

3) 長谷川: 学振第 122 委員会提出資料(昭36年 2 月)

4 ) R. A. Perkins, W. O. Binder: J. Metals, Feb. (1957)

5 ) 斎藤：鉄と鋼, 39 (1953) No. 1

6）横田, 他: 鉄鋼の炭化物研究会にて発表（昭35年 3月)

7）森島：鉄と鋼， 44 (1958) No.6

8) W. Austin: Contribution to the Metallurgy of Steel No. 41

9) A.I.M.E.: Basic Open Hearth Steel Making (1951) $477 \sim 482$ 